\title{
The successional phases of a periphytic algal community in a shallow tropical reservoir during the dry and rainy seasons
}

\author{
Thiago Rodrigues dos Santos and Carla Ferragut* \\ Núcleo de Pesquisas em Ecologia, Instituto de Botânica, Caixa Postal 68041, São Paulo, SP, Brazil \\ * Corresponding author: carlaferragut@yahoo.com.br
}

Received: $1 / 03 / 13$

Accepted: 10/07/13

\begin{abstract}
The successional phases of a periphytic algal community in a tropical shallow reservoir during the dry and rainy seasons

This study aims to describe the structural changes in a successional periphyton community during the dry and rainy seasons in a shallow tropical reservoir. The sources of structural variability of the periphytic algal community were identified on successional and seasonal scales. Glass slides were placed in macrophyte stands for periphyton colonisation over $30 \mathrm{~d}$. Samples were taken at intervals of hours $(24 \mathrm{~h}, 27 \mathrm{~h}, 30 \mathrm{~h}, 33 \mathrm{~h}, 45 \mathrm{~h}, 48 \mathrm{~h}, 51 \mathrm{~h}, 54 \mathrm{~h}$, and $57 \mathrm{~h})$ and days $(3 \mathrm{~d}, 6 \mathrm{~d}, 9 \mathrm{~d}, 12 \mathrm{~d}$, $15 \mathrm{~d}, 20 \mathrm{~d}, 25 \mathrm{~d}$, and $30 \mathrm{~d}$ ). The limnological conditions differed significantly between the dry and rainy seasons. The biomass increment, total density, and total biovolume increased as the colonisation time increased in both climatic periods. A CCA showed the influence of seasonal and successional scales on periphytic algal community structure. The replacement of species and structural-attribute variation furnished evidence for the occurrence of two successional phases (early and advanced) over $30 \mathrm{~d}$ of periphyton colonisation in both climatic periods. These successional stages were distinguished primarily by the species composition and successional trajectory. On a seasonal scale, the availability of light and nutrients were the factors that determined the organisation of the periphyton community. In conclusion, the duration of the successional phases and species trajectory during periphyton colonisation was influenced by seasonality (allogenic factors) and differential species performance (autogenic factors) in a shallow tropical reservoir.
\end{abstract}

Key words: Artificial substrate, diversity, periphyton, species composition, seasonality.

\section{RESUMEN}

Etapas de la sucesión de la comunidad de algas perifíticas en un embalse tropical somero durante los períodos de sequía y lluvia

Este estudio describe los cambios estructurales en la sucesión de las algas perifíticas durante los períodos de sequía y lluvia en un embalse tropical somero. Las fuentes de variabilidad estructural de la comunidad perifítica de algas fueron identificadas a nivel de escala sucesional y estacional. Láminas de vidrio fueron dispuestas como substratos artificiales, en bancos de macrófitos para su colonización en un período de tiempo de 30 días. Las muestras fueron tomadas en intervalos de horas $(24 h, 27 h, 30 h, 33 h, 45 h, 48 h, 51 h, 54 h, 57$ h) y días $(3 d, 6 d, 9 d, 12 d, 15 d, 20 d, 25 d y 30 d)$. Las condiciones limnológicas entre los períodos lluviosos y secos fueron significativamente diferentes. El incremento en la biomasa, la densidad total y el biovolumen total aumentaron en tanto se incrementaba el tiempo de colonización en ambos períodos climáticos. El ACC mostró la influencia a nivel estacional y sucesional de la estructura de la comunidad perifítica. La sustitución de especies y la variación de los atributos estructurales marcaron la existencia de dos fases (estadio de sucesión temprano y avanzado), en el periodo de 30 días de colonización perifítica en ambos períodos climáticos. Estas etapas se distinguían principalmente por la composición de especies. La disponibilidad de luz y nutrientes fueron factores determinantes en la organización de la comunidad perifítica. En conclusión, la duración de las fases y la trayectoria de las especies durante la colonización perifítica estuvieron determinadas por la estacionalidad (factores alógenos) y por el comportamiento de cada una de las especies (factores autógenos) en este embalse tropical somero.

Palabras clave: Sustrato artificial, diversidad, perifíton, composición de especies, estacionalidad. 


\section{INTRODUCTION}

The successional process in periphytic algal communities depends on a complex suite of interactions between physical habitat characteristics, allogenic factors, autogenic changes in the community, and species composition (McCormick \& Stevenson, 1991). Among environmental factors, resources (light and nutrients) and space availability are the principal determinants of species colonisation and result in differential species performance (Stevenson, 1996). The ability of periphytic algae to successfully colonise the substrate and persist in the community depends on the efficiency of the adaptive strategies used in competing for resources (Ferragut \& Bicudo, 2010). Observational and experimental studies have shown that the successional process followed by the periphytic algae can be directional and predictable in a tropical reservoir (e.g., Vercellino \& Bicudo, 2006; Ferragut \& Bicudo, 2012). Thus, changes in the successional trajectory of the species can aid in the detection and prediction of changes in environmental conditions.

In tropical lentic ecosystems, the mechanisms of algal succession and the environmental factors that determine seasonal patterns of community development are not well understood. In tropical lakes and reservoirs, experimental studies have shown that resource availability (light and nutrients) is a determinant of the trajectory and successional dynamics of periphytic algal communities (Sekar et al., 2002; Ferragut \& Bicudo, 2010). In eutrophic reservoirs, the intensity of cyanobacterial blooms determines structural changes during algal succession (Borduqui \& Ferragut, 2012). Moreover, the periphytic algal succession in an Amazonian lake was determined by variations in the water level (França et al., 2011). The hydrological period was the primary determinant of the periphyton structure and successional dynamics in the Upper Paraná River floodplains (Rodrigues \& Bicudo, 2004). Overall, these previous investigations have shown that the successional sequence of periphytic algae is driven by variability in environmental factors, but no factors determining the successional patterns in shallow tropical reservoirs have yet been identified.

This study is based on the assumption that algal reproduction can occur over an extremely short time interval and that the periphytic community structure can, for this reason, change very rapidly (Lee, 2008; Ács \& Kiss, 1993), particularly in tropical regions where climatic conditions are highly favourable for algal growth. Accordingly, the study aims to describe the structural changes in a successional periphyton community during the dry and rainy seasons, including many details of the early successional stage and the identification of successional phases in a
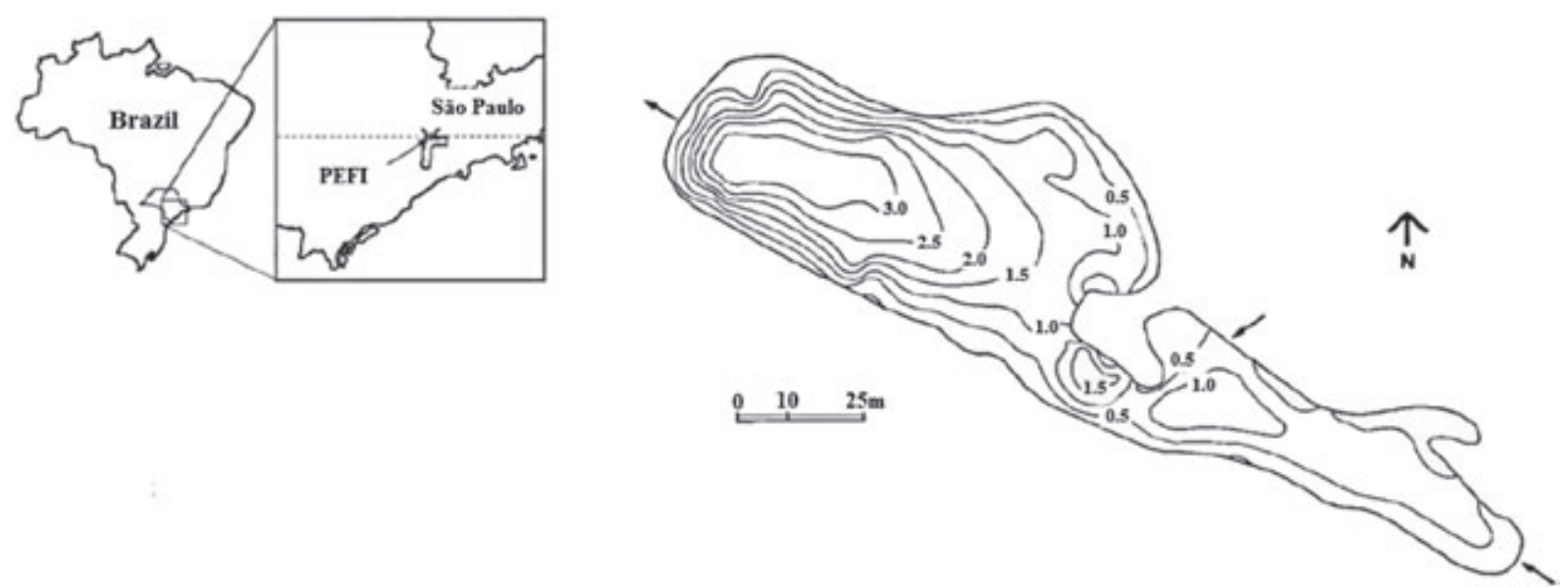

Figure 1. Ninféias Reservoir map with locations of inflows, outlet and sampling station () (adapted from Bicudo et al., 2002). Mapa del embalse Ninféias con la ubicación de las entradas, salida y lugar de muestreo (adaptado de Bicudo et al., 2002). 
shallow tropical reservoir. In general, this study may contribute to a better understanding of periphyton dynamics in shallow tropical ecosystems.

\section{MATERIALS AND METHODS}

\section{Study Area}

The site of this study was Ninféias Reservoir, located in the Parque Estadual das Fontes do Ipiranga $\left(23^{\circ} 38^{\prime} 18.95^{\prime \prime} \mathrm{S}, 46^{\circ} 37^{\prime} 16.3^{\prime \prime} \mathrm{W}\right)$ in the municipality of São Paulo, in southeastern Brazil (Fig. 1). This reservoir is a shallow mesotrophic and polymictic system with a surface area of $5433 \mathrm{~m}^{2}$, a volume of $7170 \mathrm{~m}^{3}$, a mean depth of $1.32 \mathrm{~m}$, a maximum depth of $3.6 \mathrm{~m}$, and a mean theoretical residence time of $7 \mathrm{~d}$ (Bicudo et al., 2002). The littoral zone has an abundant macrophyte flora. The year is divided into two climatic periods: a dry period with lower air temperatures during autumn and winter (March-August, accumulated precipitation: $112.0 \mathrm{~mm}$, annual average) and a rainy period with higher temperatures during spring and summer (September-February, accumulated precipitation: $119.8 \mathrm{~mm}$, annual average).

\section{Sampling climate and limnological variables}

The sampling of periphyton and physical and chemical variables was performed from July 4 to August 3, 2007 (dry period) and from January 9 to February 8, 2008 (rainy period). Glass slides $(76 \mathrm{~mm} \times 26 \mathrm{~mm})$ were used as artificial substrata for periphyton development. One hundred eighty glass slides were fixed vertically in a wood frame and submerged to a depth of $30 \mathrm{~cm}$ inside the aquatic macrophyte stands. The sampling intervals were selected based on the dynamics of the periphytic communities of reservoirs in the study area (e.g., Vercellino \& Bicudo, 2006). The first sampling was performed after $24 \mathrm{~h}$ of substrate exposure, and the subsequent sampling intervals were 3 and $12 \mathrm{~h}(24 \mathrm{~h}, 27 \mathrm{~h}, 30 \mathrm{~h}, 33 \mathrm{~h}$, $45 \mathrm{~h}, 48 \mathrm{~h}, 51 \mathrm{~h}, 54 \mathrm{~h}$, and $57 \mathrm{~h}$ ). After the $3^{\text {rd }}$ day of colonisation, the sampling intervals were $3 \mathrm{~d}$ up to the $15^{\text {th }}$ day of periphyton succession followed by 5 -d intervals until day 30 ( $3 \mathrm{~d}, 6 \mathrm{~d}$,
9 d, 12 d, 15 d, 20 d, 25 d, and 30 d). Periphyton was collected by random sampling of glass slides and was removed from the substrate by scraping and rinsing with distilled water.

Temperature and rainfall data were provided by the Meteorological Station of the CIENTEC, Centro de Ciências e Tecnologia da Universidade de São Paulo (estacao.iag.usp.br).

The following variables were measured on the sampling days: temperature, subaquatic radiation (Licor LI-250A Lincoln, Nebraska, USA), alkalinity (Golterman \& Clymo, 1971), free $\mathrm{CO}_{2}$ (Mackeret et al., 1978), conductivity (Digimed DM-32, São Paulo, Brazil), dissolved oxygen (Golterman et al., 1978), pH (pHmetro, Digimed DM-20, São Paulo, Brazil), and total nitrogen and phosphorus (Valderrama, 1981).

\section{Periphyton}

Periphyton chlorophyll $a$ was determined from samples filtered $(n=2)$ by a glass-fibre filter (Whatman GF/F) using ethanol (90\%) as extractor (Marker et al., 1980; Sartory \& Grobblelar, 1984). The measurement of chlorophyll $a$ was performed only after the $3^{\text {rd }}$ day of colonisation due to the scarcity of periphytic material on the substrate in the early stages. Samples $(n=1)$ for taxonomy were preserved with $4 \%$ aqueous formaldehyde, and permanent diatom slides were prepared using the method of Battarbee (1986). Samples for quantitative analyses were adjusted to a constant volume with distilled water and preserved with acetic Lugol's solution. Algal quantifications were performed using a Zeiss Axiovert microscope $(400 \times)$ and following Utermöhl (1958). The sedimentation time in the chamber was determined according to Lund et al. (1958). The counting limit was established by the rarefaction curve of species and the minimum count of 100 individuals of the most abundant species (Bicudo, 1990). Biovolume was obtained by geometric approximation (Hillebrand et al., 1999) and was calculated by multiplying each species' density by its average volume $\left(\mu \mathrm{m}^{3}\right.$ $\mathrm{cm}^{-2}$ ). Most algal biovolumes were obtained from the database of the Aquatic Ecology Laboratory, Instituto de Botânica (unpublished data). 
Table 1. Minimum and maximum values, with mean values $(n=10)$ in parentheses, and standard deviation of abiotic variables in aquatic macrophyte stands during the dry and rainy periods. The last column presents the results of a one-way ANOVA. Valores mínimos y máximos, entre paréntesis valores medios $(\mathrm{n}=10)$ y la desviación estándar de las variables abióticas en bancos de macrófitos acuáticos en el período seco y lluvioso. La última columna contiene los resultados del ANOVA de una vía.

\begin{tabular}{|c|c|c|c|}
\hline & Dry Period & Rainy Period & ANOVA 1-way \\
\hline Alkalinity $\left(\mathrm{mEq} \cdot \mathrm{L}^{-1}\right)$ & $\begin{array}{c}0.09-0.22 \\
(0.19 \pm 0.04)\end{array}$ & $\begin{array}{c}0.21-0.29 \\
(0.26 \pm 0.03)\end{array}$ & $\begin{array}{c}F=18.7 \\
p<0.001\end{array}$ \\
\hline Free $\mathrm{CO}_{2}\left(\mathrm{mg} \cdot \mathrm{L}^{-1}\right)$ & $\begin{array}{c}6.13-119.66 \\
(21.50 \pm 34.81)\end{array}$ & $\begin{array}{c}6.54-15.99 \\
(10.05 \pm 2.63)\end{array}$ & ns \\
\hline Conductivity $\left(\mu \mathrm{S} \cdot \mathrm{cm}^{-1}\right)$ & $\begin{array}{c}49.15-57.35 \\
(52.51 \pm 3.01)\end{array}$ & $\begin{array}{l}50.60 \pm 55.85 \\
(53.95 \pm 2.03)\end{array}$ & ns \\
\hline Dissolved oxygen (mg.L $\left.\mathrm{L}^{-1}\right)$ & $\begin{array}{c}0.59-5.75 \\
(3.89 \pm 1.40)\end{array}$ & $\begin{array}{c}3.06-5.34 \\
(4.36 \pm 0.77)\end{array}$ & ns \\
\hline Subaquatic radiation $(\%)$ & $\begin{array}{c}13.66-73.34 \\
(41.82 \pm 18.37)\end{array}$ & $\begin{array}{c}1.11-55.39 \\
(23.42 \pm 16.01)\end{array}$ & $\begin{array}{c}F=5.7 \\
p=0.028\end{array}$ \\
\hline Subaquatic radiation $\left(\mu \mathrm{mol} \cdot \mathrm{s}^{-1} \cdot \mathrm{m}^{-2}\right)$ & $\begin{array}{c}47.2-512.8 \\
(231.6 \pm 177.3)\end{array}$ & $\begin{array}{c}26.6-884.9 \\
(415.8 \pm 69.1)\end{array}$ & $\begin{array}{c}F=7.5 \\
p=0.013\end{array}$ \\
\hline $\mathrm{pH}$ & $\begin{array}{c}4.93-6.58 \\
(6.23 \pm 0.50)\end{array}$ & $\begin{array}{c}6.22-6.61 \\
(6.42 \pm 0.10)\end{array}$ & ns \\
\hline Temperature $\left({ }^{\circ} \mathrm{C}\right)$ & $\begin{array}{c}12.00-18.00 \\
(15.76 \pm 1.75)\end{array}$ & $\begin{array}{c}20.00-26.00 \\
(23.10 \pm 1.84)\end{array}$ & $\begin{array}{l}F=83.69 \\
p<0.001\end{array}$ \\
\hline Total Nitrogen $\left(\mu \mathrm{g} \cdot \mathrm{L}^{-1}\right)$ & $\begin{array}{c}85.91-580.91 \\
(265.17 \pm \\
197.69)\end{array}$ & $\begin{array}{c}249.54-482.81 \\
(334.96 \pm \\
77.99)\end{array}$ & ns \\
\hline Total Phosphorus $\left(\mu \mathrm{g} \cdot \mathrm{L}^{-1}\right)$ & $\begin{array}{c}11.37-17.04 \\
(14.03 \pm 2.03)\end{array}$ & $\begin{array}{c}19.28-32.83 \\
(24.68 \pm 4.40)\end{array}$ & $\begin{array}{l}F=48.34 \\
p=0.002\end{array}$ \\
\hline
\end{tabular}

A species was considered dominant if its biovolume was greater than $50 \%$ of the total sample biovolume. The Shannon diversity index (bits ind ${ }^{-1}$ ) and evenness were used as measures of community structure (Magurran, 2004). Species richness was defined as the number of species per sample.

\section{Statistical Analysis}

The coefficient of variation (CV) was used to compare the degree of variation in environmental variables and periphytic community attributes over time. A one-way analysis of variance (ANOVA)

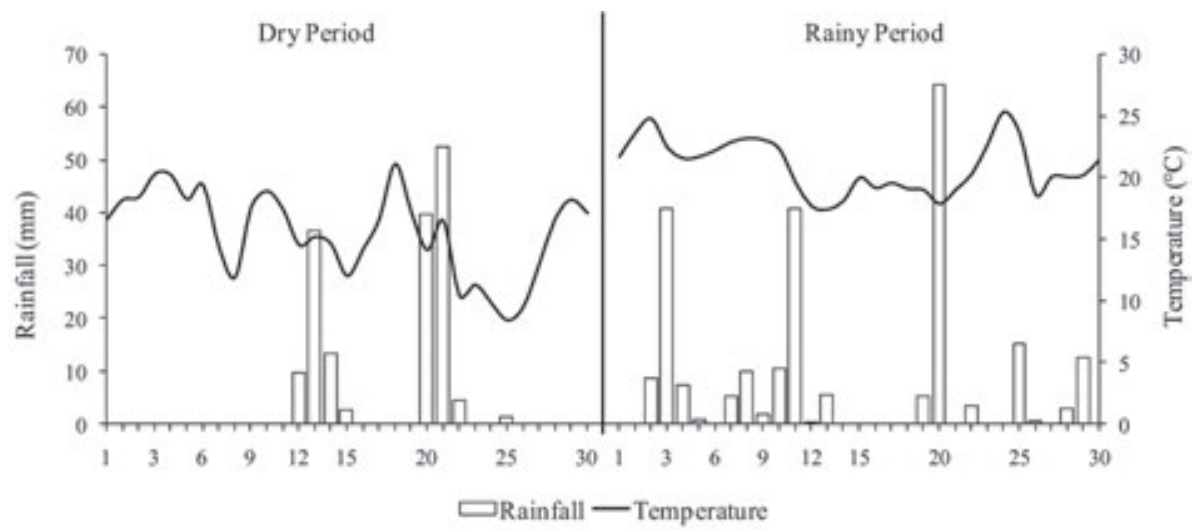

Figure 2. Mean daily variation in air temperature and rainfall during the study period. Variación media diaria de la temperatura del aire y precipitación en el período de estudio. 
was applied to evaluate the significance of differences between climatic periods $(p>0.05)$.

Multivariate analysis was performed by applying a canonical correspondence analysis (CCA) to environmental variables and species density ( $\geq 3 \%$ total density in each successional stage) using a covariance matrix with $\log (x+1)$ transformed data. A Monte Carlo randomisation test (999 permutations) was used to select the dimension for CCA interpretation ( $p \leq 0.05)$. PC-ORD 6.0 software for Windows (McCune \& Mefford, 2011) was used for the analysis.

A

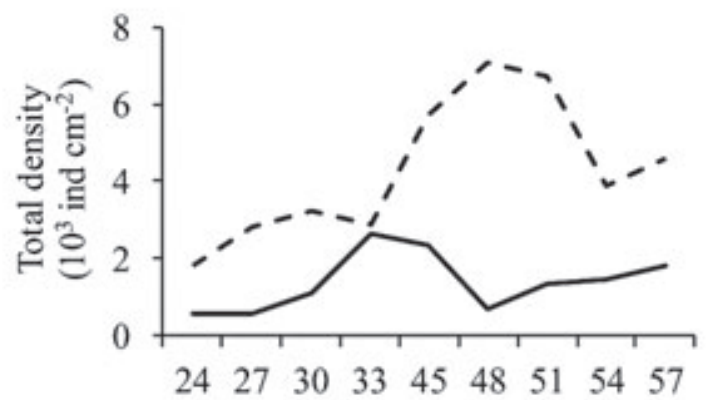

C

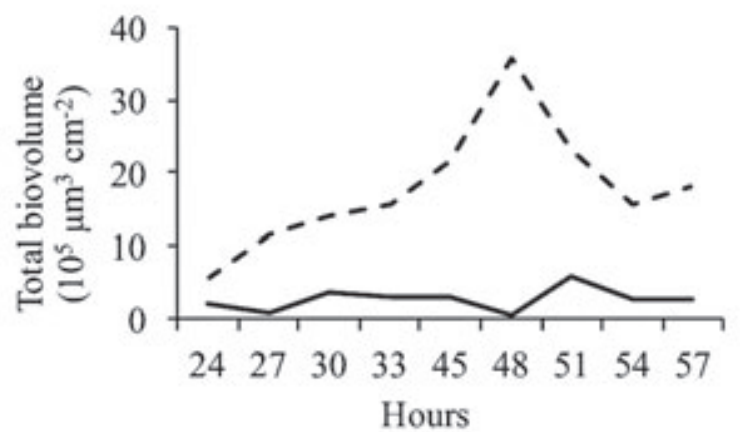

$\longrightarrow$ Dry - - Rainy

\section{RESULTS}

\section{Climate Variables}

The monthly average air temperature and rainfall were higher in the rainy period $\left(20.8^{\circ} \mathrm{C}\right.$; $228.4 \mathrm{~mm})$ than in the dry period $\left(15.4^{\circ} \mathrm{C}\right.$; $160.9 \mathrm{~mm}$ ) (Fig. 2). Several heavy rainfalls occurred during the dry $\left(13^{\text {rd }}, 20^{\text {th }}\right.$, and $21^{\text {st }}$ day $)$ and rainy $\left(3^{\text {rd }}, 11^{\text {th }}\right.$, and $20^{\text {th }}$ day) seasons.

B

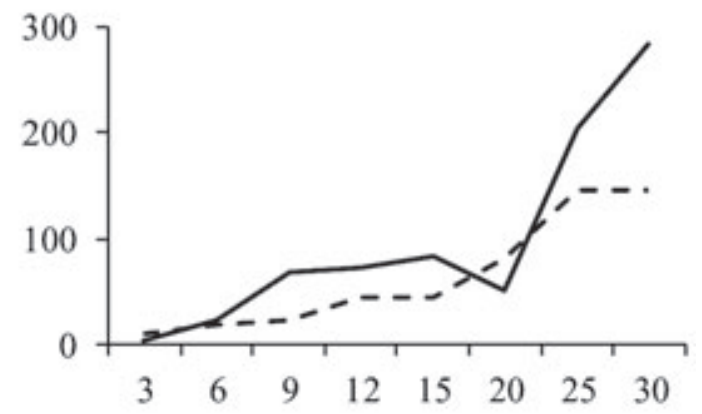

D
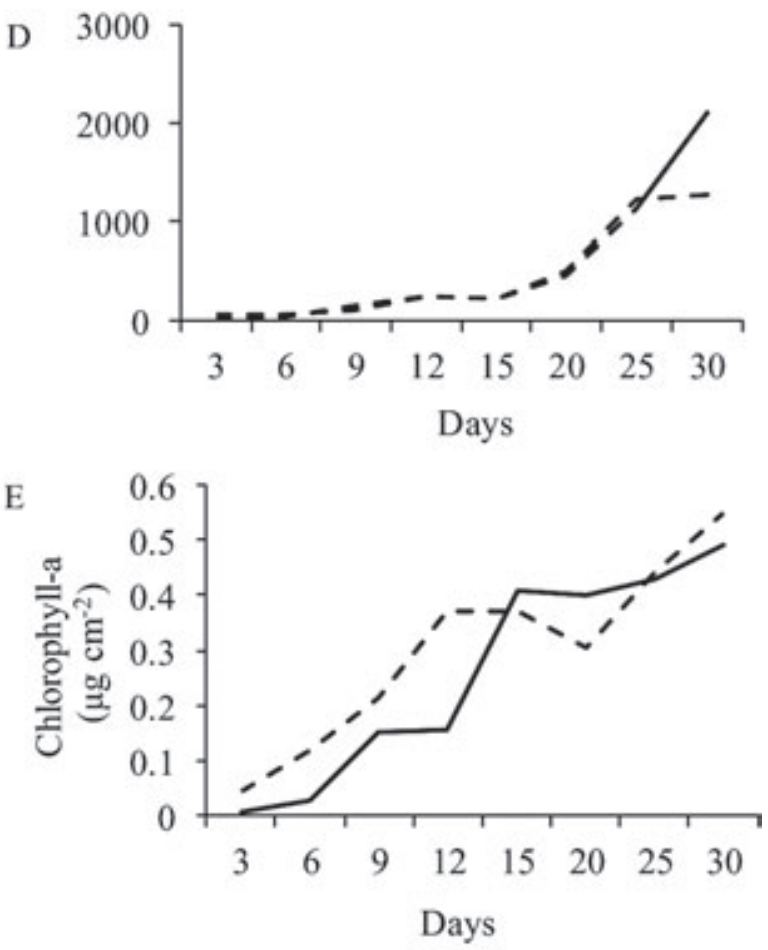

Figure 3. Total density, total biovolume and chlorophyll $a(n=2)$ of periphytic algae during succession in the dry and rainy periods. Densidad total, biovolumen total y clorofila a $(\mathrm{n}=2)$ del perifiton durante la sucesión en el período seco y lluvioso. 


\section{Limnological Variables}

Table 1 summarises the physical and chemical variables $(n=10)$ during the sampling period. The dry period was characterised by a high free$\mathrm{CO}_{2}$ concentration and the rainy period by high values of underwater radiation, temperature, conductivity, dissolved oxygen and TP concentration., The water was slightly acidic during both periods (on average, dry: 6.2; rainy: 6.4 ). The TP concentration was 1.7 times higher in the rainy period than in the dry period, whereas the TN concentration was elevated during both periods. Alkalinity, subaquatic radiation, temperature and TP concentration differed significantly between the climatic periods (Table 1).

\section{Periphytic Community}

Qualitatively, 100 taxa were identified in the dry period, 27 of which were found exclusively during this period. In the rainy period, 97 taxa were identified, 24 of which were found exclusively during this period. During the study period, 141 taxa belonging to 9 algal classes were identified. Chlorophyceae (46 species) and Zygnemaphyceae (29 species) had the greatest number of species.

The dry period had more rare species than the rainy period (39 and 23, respectively). Chromulina elegans was the only species that occurred throughout the successional process in the dry season (100\% frequency of occurrence). In the rainy season, three species showed a $100 \%$
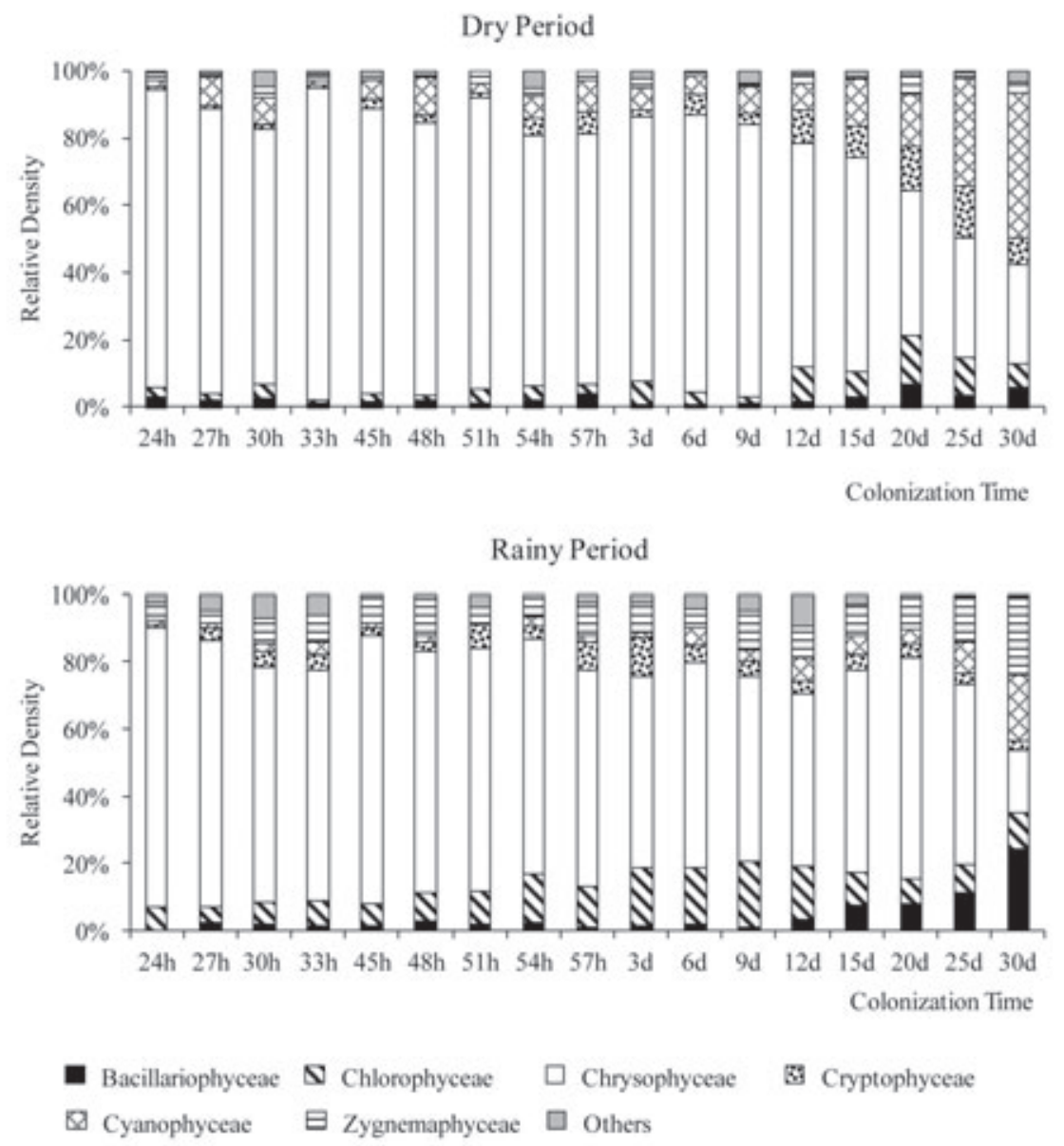

Figure 4. Relative density of periphytic algal classes during succession in the dry and rainy periods. Densidad relativa de las clases de algas perifíticas durante la sucesión en el período seco y lluvioso. 
frequency of occurrence: Monoraphidium irregulare, C. elegans, and Closterium gracile.

The total algal density and biovolume showed a slight fluctuation in the initial stages but tended to increase from the $3^{\text {rd }}$ day as the colonisation time increased during the dry and rainy seasons (Fig. 3A-D). After $3 \mathrm{~d}$ of colonisation, the algal biomass increment was continuous in both climatic periods (Fig. 3E).

In terms of density, the Chrysophyceae was the dominant group in the periphytic community structure until the $15^{\text {th }}$ and $25^{\text {th }}$ day of colonisation in the dry $(87 \%)$ and rainy $(67 \%)$ periods, respectively (Fig. 4). The participation of Chrysophyceae in the community structure decreased as the successional process advanced. The density of Chlorophyceae and Cyanophyceae increased substantially in the later successional stages during the dry period. In contrast, the relative density of Bacillariophyceae, Cyanophyceae, and Zygnemaphyceae increased in advanced successional stages in the rainy season.

The most abundant Chrysophyceae species was Chromulina elegans, which was present at a high density throughout the succession in both climatic periods (dry $=41 \%$; rainy $=43 \%$, on average) (Fig. 5).

Chromulina sphaerica Bachmann and C. elegans (dominant, $50.8 \%$ on average) were the most abundant species from the early stages until the $25^{\text {th }}$ day in the rainy period. In the dry period, C. elegans was dominant until the $15^{\text {th }}$ successional stage ( $76 \%$ on average), whereas Cryptomonas tenuis Pascher and the cyanobacteria Pseudanabaena galeata, Leptolyngbya tenuis, and Aphanocapsa elachista increased in density
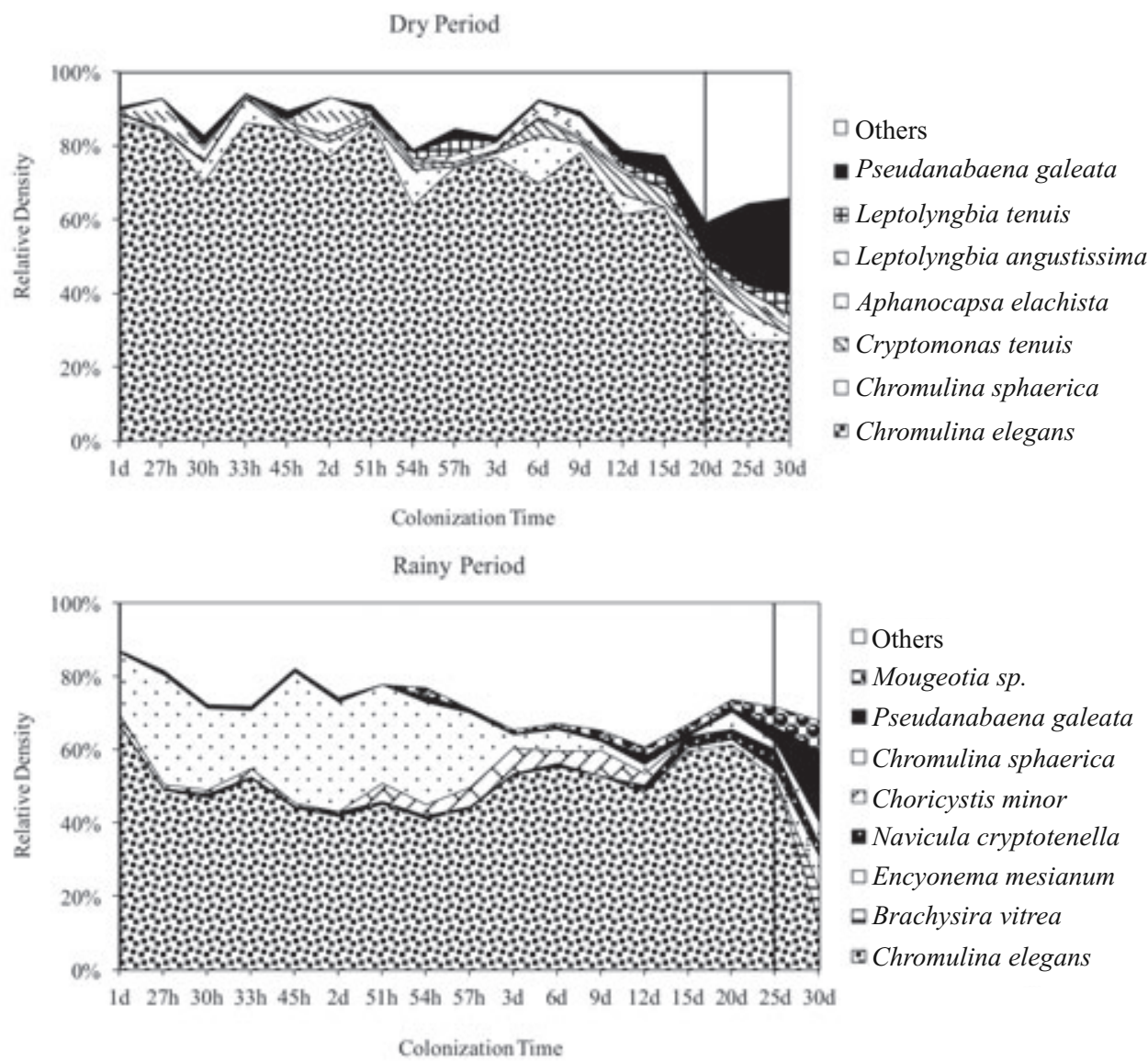

Figure 5. Relative density of periphytic descriptor species ( $\geq 3 \%$ of total density) during succession in the dry and rainy periods. Densidad relativa de especies descriptivas del perifiton durante la sucesión en el período seco y lluvioso. 
in the advanced stages (20-30 $30^{\text {th }}$ day). In the rainy period, Pseudanabaena galeata, Mougeotia spp., and Encyonema mesianum were the most abundant species in the advanced successional stages (30 ${ }^{\text {th }}$ day) (Fig. 5).

In terms of algal biovolume, Zygnemaphyceae was strongly represented in the community during the rainy period (55.8\% on average), followed by Closterium setaceum Ehrenberg ex Ralfs, Cosmarium bioculatum Brébisson ex Ralfs, Mougeotia spp., and Cosmarium margaritatum (P.Lundell) J.Roy \& Bisset (Fig. 6). Despite the substantial participation of Zygnemaphyceae in the dry period as well $(38.2 \%$, on average), the Bacillariophyceae biovolume was high, primarily Pinnularia divergens W. Smith (21.4\%, on average).

Diversity and evenness tended to increase with advancing succession in both climatic periods (Fig. 7). Species richness varied during succession but increased slightly with colonisation time. The highest diversity andevenness were recorded in the rainy period, whereas the highest species richness was found in the dry period.

A CCA performed with 41 periphytic algal species ( $3 \%$ of total density in each successional stage) and 6 abiotic (environmental) variables (Fig. 8) resulted in eigenvalues of 0.140 and 0.068 for the first two axes. The first two axes explained $25.9 \%$ of the total variance in the species data. The high Pearson correlation between the species and environmental data for both axes $(r=0.961$ and $r=0.853)$ indicated a strong relationship between the species distributions and the environmental variables. A Monte Carlo permutation test was significant for both axes $(p=0.01)$. The canonical coefficients identified temperature and TP as the principal environmental variables in the ordination (Table 2).

On the positive side of axis 1 , all units for the rainy season were highly correlated with the highest values of temperature and TP $(r=0.9$; Table 3). Six species of periphytic algae were associated with the rainy season $(r \leq 0.5)$, es-

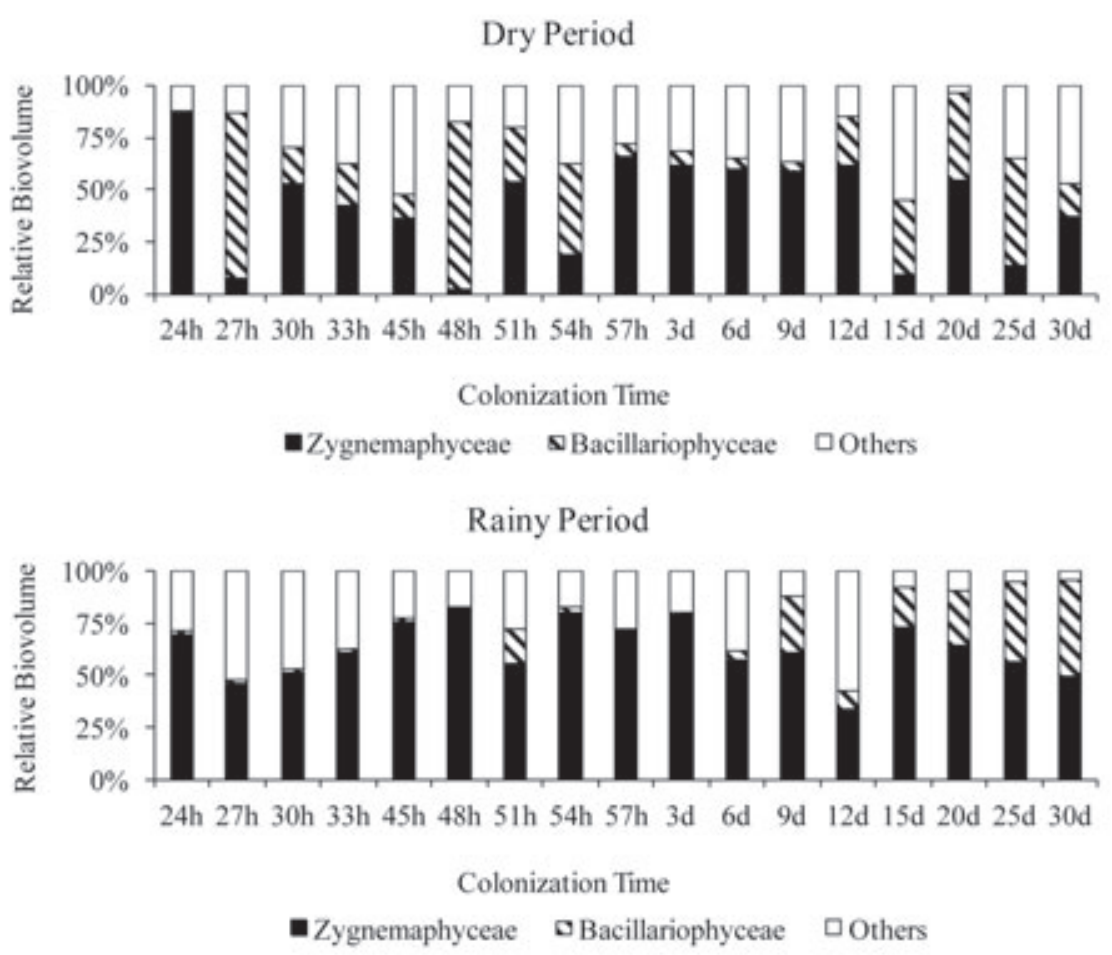

Figure 6. Relative biovolume of periphytic algal classes during succession in the dry and rainy periods. Biovolumen relativo de las clases de algas perifíticas durante la sucesión en el período seco y lluvioso. 
Table 2. Canonical coefficients and Pearson correlations for the six environmental variables selected for the CCA analysis. Coeficiente canónico y correlación de Pearson en seis variables ambientales seleccionado para el análisis (CCA).

\begin{tabular}{lcrrrr}
\hline & \multicolumn{2}{c}{ Canonical coefficients } & \multicolumn{2}{c}{ Pearson correlation } \\
\hline Environmental variables & Code & \multicolumn{1}{c}{ Axis 1 } & Axis 2 & Axis 1 & Axis 2 \\
\hline Conductivity & Cond & 0.380 & 0.035 & 0.38 & 0.29 \\
pH & $\mathrm{pH}$ & 0.199 & -0.422 & 0.35 & 0.29 \\
Subaquatic radiation & Rad & -0.443 & 0.295 & 0.18 & 0.32 \\
Temperature & Temp & 0.481 & -0.294 & 0.89 & -0.01 \\
Total nitrogen & TN & 0.042 & -1.345 & 0.26 & -0.91 \\
Total phosphorus & TP & 0.521 & 0.547 & 0.88 & -0.32 \\
\hline
\end{tabular}

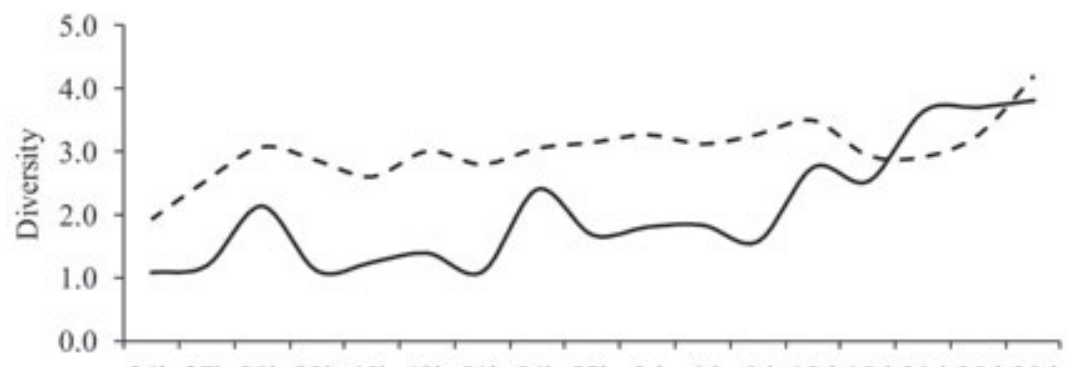

$24 \mathrm{~h} 27 \mathrm{~h} 30 \mathrm{~h} 33 \mathrm{~h} 45 \mathrm{~h} 48 \mathrm{~h} 5 \mathrm{lh} 54 \mathrm{~h} 57 \mathrm{~h} 3 \mathrm{~d} 6 \mathrm{~d} 9 \mathrm{~d} 12 \mathrm{~d} 15 \mathrm{~d} 20 \mathrm{~d} 25 \mathrm{~d} 30 \mathrm{~d}$

Colonization time

- Dry - - Rainy

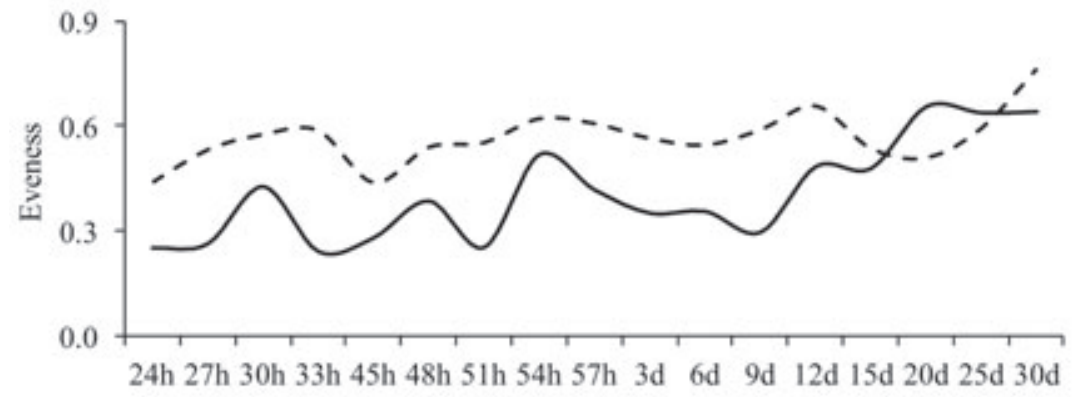

Colonization time

- Dry - - - Rainy

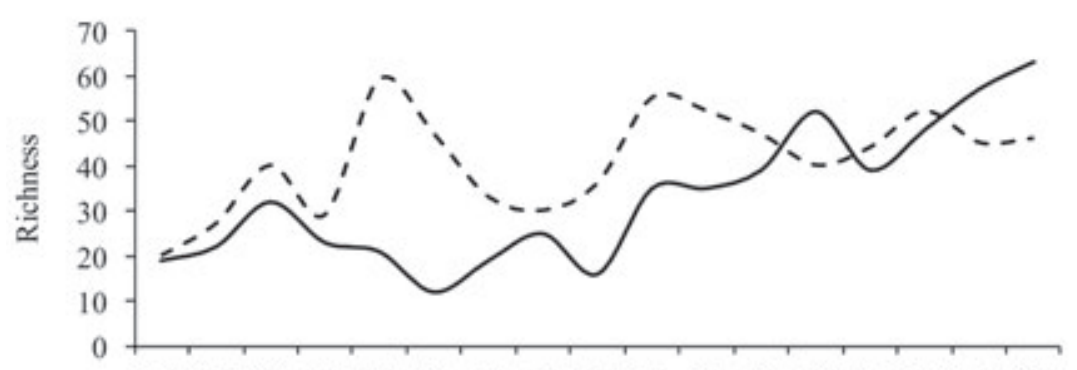

$24 \mathrm{~h} 27 \mathrm{~h} 30 \mathrm{~h} 33 \mathrm{~h} 45 \mathrm{~h} 48 \mathrm{~h} 5 \mathrm{lh} 54 \mathrm{~h} 57 \mathrm{~h} 3 \mathrm{~d} 6 \mathrm{~d} 9 \mathrm{~d} 12 \mathrm{~d} 15 \mathrm{~d} 20 \mathrm{~d} 25 \mathrm{~d} 30 \mathrm{~d}$

Colonization Time

- Dry - - Rainy

Figure 7. Periphytic algal diversity, evenness and species richness during succession in the dry and rainy periods. Diversidad, equidad y riqueza de especies de algas perifíticas durante la sucesión en el período seco y lluvioso. 


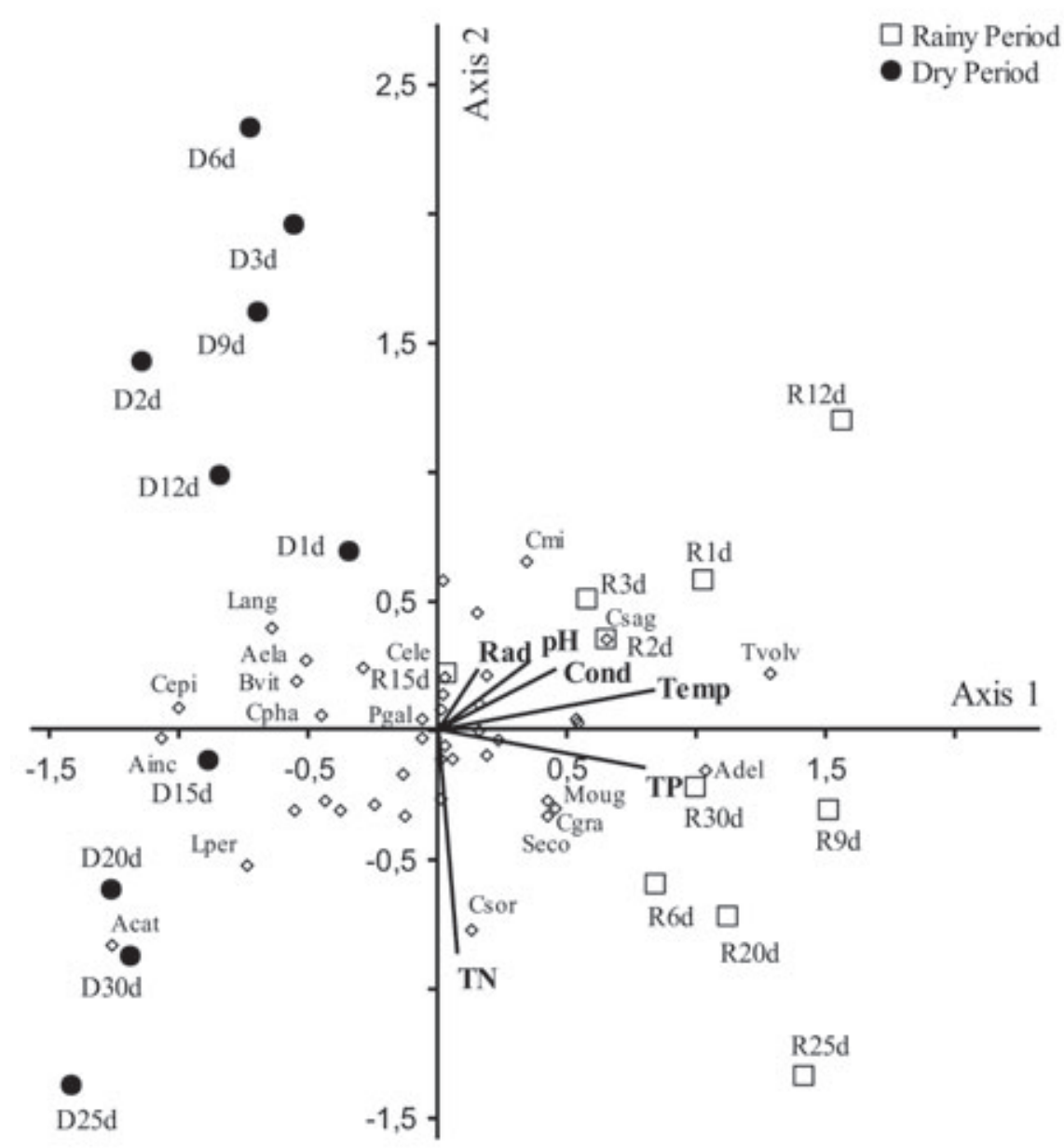

Figure 8. CCA diagram of periphytic algal density during succession in the dry and rainy periods. Score abbreviations: first letters refer to climatic period ( $\mathrm{D}=$ dry; $\mathrm{R}=$ rainy) and numbers to colonisation time (d). For species correlations with axes 1 and 2 and species codes, see tables 2 and 3. Diagrama de CCA de la densidad de algas perifíticas durante la sucesión en el período seco y lluvioso. Abreviaturas de los scores: primera letra corresponde a la época climática $(D=s e c o ; R=l l u v i o s o)$ y los números al tiempo de colonización (días). Para la correlación de las especies con los ejes 1 y 2, y respectivos códigos (ver tablas 2 y 3).

pecially Aphanocapsa delicatissima $(r=0.8)$, Monoraphidium irregulare $(r=0.7)$, and Cosmarium blyttii $(r=0.6)$. On the negative side of axis 1 , all units from the dry period were related to the lowest TP and temperature values. A group of seven species, especially the small flagellated Chlamydomonas epibiotica $(r=-0.8)$, was associated with the dry period. Therefore, the first axis showed the influence of seasonal scale on periphyton community structure.

On the negative side of axis 2 , all units of the advanced successional stages (15-30 d) in the dry and rainy seasons were highly correlated with the highest TN concentration. Filamentous Leptolyn- gbya tenuis and Mougeotia spp. and unicellular desmid Closterium gracile showed high negative correlations with axis $2(r=-0.7)$. Choricystis minor showed the greatest association with the early successional stages $(r=0.32)$. Therefore, axis 2 represented the succession of periphytic algae.

\section{DISCUSSION}

Periphytic community development was influenced by seasonal changes of limnological conditions within macrophyte stands in a shallow mesotrophic reservoir (Ninféias Reservoir). 
Based on the results of a CCA, TP concentration and water temperature were identified as determinants of the structural differences in the periphytic algal community on a seasonal scale. The replacement of species and structural-attribute variation showed that two successional phases (early and advanced successional stages) occurred over $30 \mathrm{~d}$ of periphyton colonisation in both climatic periods. These successional stages were distinguished primarily by species composition and the successional trajectory of the species.

Despite heavy rainfall events that caused a loss of biomass and reduced algal growth in several successional stages, the successional trajectory of the species did not change. Chromulina elegans was dominant in the community structure from the initial stages to 20-25 d of colonisation. Algal community persistence is highly dependent on the ability to resist disturbances, such as rain, currents, or disturbances by animals (Stevenson, 1996).

The success of Chrysophyceae in the periphyton can be explained by opportunistic characteristics and competitive advantages, such as switches among the processes of autotrophy, heterotrophy and phagotrophy in response to nutrient availability in the system (Sandgren, 1988). Previous studies have reported the success of Chromulina elegans in the early successional stages of periphyton in an oligotrophic tropical reservoir (Ferragut \& Bicudo, 2012) and in a mesotrophic tropical reservoir (Fermino et al., 2011; Pellegrini \& Ferragut, 2012) within the study area. The presence of flagella, which facilitates the search for resources, rapid reproduction, and a higher surface/volume ratio, is an adaptive strategy that ensures the success of $C$. elegans in the periphyton (Happey-Wood, 1988). The substantial participation of loosely attached algae (without a structure for attachment to the substrate), such as flagellated algae, in the periphyton is commonly reported in tropical reservoirs, especially in the early successional stages (Rodrigues \& Bicudo, 2004; Vercellino \& Bicudo, 2006; França et al., 2011).

In terms of biovolume, Zygnemaphyceae and Bacillariophyceae were highly representative of the community structure of the periphytic algae. The desmids Cosmarium margaritatum and
Closterium setaceum were the most representative species in the early successional stages, and Mougeotia spp. were most representative at later stages in the rainy season. A high abundance of Zygnemaphyceae is generally associated with the presence of macrophytes in an oligotrophic environment (Coesel, 1982). Thus, desmids in the periphyton were favoured by limnological conditions and high macrophyte coverage (unpublished data), even in the early stages. This algal group possesses adaptive characteristics that allow rapid development on denuded substrates. For example, the surface/volume ratio of desmids increases their access to light (Domozych \& Domozych, 2007).

In terms of biovolume, diatoms also contributed substantially to community structure during the successional process, especially in the dry season. Pinnularia divergens made the greatest contribution to total biovolume, especially in advanced successional stages in the dry season. This species has been associated with high $\mathrm{N}$ availability in an experimental study and with an increase of the mixing zone during the dry season (Fermino et al., 2011; Fonseca \& Bicudo, 2010). Moreover, Cyanophyceae exhibited high density and biovolume in advanced successional stages in both climatic periods, especially filamentous forms such as Pseudanabaena galeata and Leptolyngbya tenuis. An increase in filamentous forms in the advanced successional stages is characteristic of the physiognomy of the periphyton and is commonly reported in streams, rivers, and reservoirs (Biggs, 1996; Fesliberto \& Rodrigues, 2012; Sekar et al., 2004).

Algal diversity and richness increased with increasing colonisation time, demonstrating the constant arrival of new colonisers. In tropical ecosystems, previous studies have reported a positive relationship between algal diversity and colonisation time (Felisberto \& Rodrigues, 2012; França et al., 2011), whereas other studies have reported negative relationships (Borduqui \& Ferragut, 2012) or little variation during colonisation (Vercellino \& Bicudo, 2006). According to Hillebrand \& Sommer (2000), the relationship between algal diversity and colonisation time can vary with environmental conditions. For 
Table 3. Pearson correlations $(r)$ of species with axes 1 and 2 of CCA, showing the identifying codes for the species. Correlación de Pearson (r) de las especies con los ejes 1 y 2 de la CCA, y sus respectivos códigos.

\begin{tabular}{|c|c|c|c|}
\hline Species & Code & Axis $1(r)$ & Axis $2(r)$ \\
\hline Achnanthidium catenatum (Bily \& Marvan) Lange-Bertalot & Acat & -0.45 & -0.38 \\
\hline Aphanocapsa delicatissima West \& G.S.West & Adel & 0.77 & -0.33 \\
\hline Aphanocapsa elachista West \& G.S.West & Aela & -0.54 & -0.01 \\
\hline Aphanocapsa incerta (Lemmermann) Cronberg \& Komárek & Ainc & -0.56 & -0.15 \\
\hline Cryptomonas tenuis Pascher & Cten & -0.06 & -0.50 \\
\hline Brachysira vitrea (Grunow) R.Ross & Bvit & -0.59 & -0.09 \\
\hline Cosmarium blyttii Wille & Cbly & 0.60 & -0.28 \\
\hline Chlamydomonas debaryana Goroschankin & Cdeb & -0.31 & -0.43 \\
\hline Chromulina elegans Doflein & Cele & -0.05 & -0.45 \\
\hline Chlamydomonas epibiotica Ettl & Cepi & -0.77 & -0.14 \\
\hline Cryptomonas erosa Ehrenberg & Cer & 0.02 & -0.44 \\
\hline Closterium gracile Brébisson ex Ralfs & Cgra & 0.55 & -0.76 \\
\hline Choricystis minor (Skuja) Fott & $\mathrm{Cmi}$ & 0.28 & 0.32 \\
\hline Cryptomonas obovata Czosnowski & $\mathrm{Cob}$ & -0.20 & -0.47 \\
\hline Cryptomonas phaseolus Skuja & Cpha & -0.53 & -0.23 \\
\hline Chlamydomonas planctogloea Skuja & Cpla & -0.12 & -0.31 \\
\hline Chlamydomonas sagittula Skuja & Csag & 0.14 & 0.01 \\
\hline Chlamydomonas sordida Ettl & Csor & 0.04 & -0.48 \\
\hline Chromulina sphaerica Bachmann & Csph & 0.29 & -0.14 \\
\hline Encyonema mesianum (Cholnoky) D.G.Mann & Eme & -0.02 & -0.60 \\
\hline Gomphonema gracile Ehrenberg & Ggra & -0.31 & -0.61 \\
\hline Leptolyngbya angustissima (West \& G.S.West) Anagnostidis \& Komárek & Lang & -0.60 & 0.10 \\
\hline Leptolyngbya perelegans (Lemmermann) Anagnostidis \& Komárek & Lper & -0.51 & -0.52 \\
\hline Leptolyngbya tenuis (Gomont) Anagnostidis \& Komárek & Lten & -0.19 & -0.70 \\
\hline Monoraphidium arcuatum (Korshikov) Hindák & Marc & 0.30 & -0.47 \\
\hline Monoraphidium contortum (Thuret) Komàrková-Legnerová & Mcont & 0.18 & -0.43 \\
\hline Monoraphidium griffithii (Berkeley) Komárková-Legnerová & Mgri & 0.18 & -0.26 \\
\hline Monoraphidium irregulare (G.M.Smith) Komárková-Legnerová & Mirr & 0.66 & -0.32 \\
\hline Mougeotia spp. & Moug & 0.51 & -0.71 \\
\hline Monoraphidium tortile (West \& G.S.West) Komárková-Legnerová & Mtor & -0.01 & -0.08 \\
\hline Navicula cryptotenella Lange-Bertalot in Krammer \& Lange-Bertalot & Ncry & -0.02 & -0.56 \\
\hline Pseudodidymocystis fina (Komárek) E.Hegewald \& Deason & Pfin & -0.35 & -0.04 \\
\hline Pseudanabaena galeata Böcher & Pgal & -0.18 & -0.55 \\
\hline Scenedesmus ecornis (Ehrenberg) Chodat & Seco & 0.42 & -0.65 \\
\hline Synechococcus nidulans (Pringsheim) Komárek & Snid & -0.02 & -0.30 \\
\hline Trachelomonas bacillifera Playfair & Tbac & -0.19 & -0.22 \\
\hline Trachelomonas curta A.M.Cunha & Tcur & -0.01 & 0.20 \\
\hline Trachelomonas lacustris Drezepolski & Tlac & 0.09 & 0.13 \\
\hline Trachelomonas oblonga Lemmermann & Tobl & -0.19 & -0.19 \\
\hline Trachelomonas volvocina (Ehrenberg) Ehrenberg & Tvol & 0.12 & -0.26 \\
\hline Trachelomonas volvocinopsis Svirenko & Tvolv & 0.56 & -0.03 \\
\hline
\end{tabular}


this reason, diversity indexes are useful for measuring environmental influences on local periphyton communities.

In summary, on a seasonal scale, the availability of light and nutrients were determining factors in periphyton community organisation. In the dry period, the early successional stage (1-15 d) was characterised by the dominance of Chromulina elegans and a high biovolume of Zygnemaphyceae (primarily Cosmarium margaritatum and Closterium setaceum). The advanced stage (20-30 d) was characterised by high diversity and species richness and by a population decline of $C$. elegans, an increased abundance of Cyanobacteria (Pseudanabaena galeata, Aphanocapsa elachista, Leptolyngynbya tenuis), and a high biovolume of Pinnularia divergens and Cosmarium margaritatum. In the rainy period, the successional process was characterised by a long early stage (1-20 d) dominated by Chrysophyceae (Chromulina sphaerica and Chromulina elegans) and showing a high biovolume of desmids (Cosmarium bioculatum, Cosmarium margaritatum and Closterium setaceum). The advanced stage (25-30 d) was characterised by high diversity, a marked decline of C. elegans, a greater abundance of Pseudanabaena galeata, Mougeotia spp., and Encyonema mesianum, and a high biovolume of Cosmarium margaritatum and Pinnularia divergens.

In conclusion, the successional process of periphytic algae was characterised by the permanence of ruderal species for several successional stages, suggesting the occurrence of very long early successional stages (1-20 d). Moreover, the high density of filamentous Zygnemaphyceae, the high biovolume of diatoms and their high diversity and richness characterised the advanced successional stage (25-30 d). The duration of the successional phases and species trajectory during $30 \mathrm{~d}$ of periphyton colonisation was influenced by seasonality (allogenic factors) and differential species performance (autogenic factors). However, the successional patterns of periphytic algal assemblies appear to result from several processes that defy explanation by a single mechanistic model (McCormick \& Stevenson, 1991). Therefore, further studies are needed to identify the successional patterns of periphyton algal community in tropical shallow lentic systems.

\section{ACKNOWLEDGEMENTS}

The authors acknowledge Fapesp (Fundação de Amparo à Pesquisa do Estado de São Paulo) for the fellowship awarded to TRS (2007/56221-4).

\section{REFERENCES}

ÁCS, E. \& K. T. KISS. 1993. Colonization process of diatoms on artificial substrates in the River Danube near Budapest (Hungary). Hydrobiologia, 269/270: 301-315.

BATTARBEE, R. W. 1986. Diatoms analysis. In: Handbook of Holocene Palaeohydrology. Berglund, B. E. (Ed): 527-570. John Wiley \& Sons, New York.

BICUDO, D. C. 1990. Considerações sobre metodologia de contagem de algas do perifíton. Acta Limnologica Brasiliensia, 3: 459-475.

BICUDO, C. E. M., C. F. CARMO, D. C. BICUDO, R. HENRY, A. C. S. PIÃO, C. M. SANTOS \& M. R. M. LOPES. 2002. Morfologia e morfometria de três reservatórios do PEFI. In: Parque Estadual das Fontes do Ipiranga: unidade de conservação ameaçada pela urbanização de São Paulo, São Paulo. BICUDO, D. C., M. C. FORTI \& C. E. M. BICUDO. (Eds.): 141-158. Secretaria do Meio Ambiente, São Paulo, Brasil.

BIGGS, B. J. F. 1996. Patterns in benthic algae of streams. In: Algal Ecology: freshwater benthic ecosystems. STEVENSON, R. J., M. L. BOTHWELL \& R. L. LOWE. (Eds.): 31-56. Academic Press, San Diego.

BORDUQUI, M. \& C. FERRAGUT. 2012. Controlling factors of successional periphytic algae in tropical hypereutrophic reservoir. Hydrobiologia, 683: 109-122.

COESEL, P. F. M. 1982. Structural characteristics and adaptations of desmids communities. Journal of Ecology, 70: 163-177.

DOMOZYCH, D. S. \& C. R. DOMOZYCH. 2007. Desmids and biofilm of freshwater wetlands: development and microarchitecture. Microbial Ecology, 55: 81-93. 
FERRAGUT, C. \& D. C. BICUDO. 2010. Periphytic algal community adaptive strategies in $\mathrm{N}$ and $\mathrm{P}$ enriched experiments in a tropical oligotrophic reservoir. Hydrobiologia, 646: 295-309.

FERRAGUT, C. \& D. C. BICUDO. 2012. Effect of $\mathrm{N}$ and $\mathrm{P}$ enrichment on successional sequence of the periphytic algae community in a tropical oligotrophic reservoir. Limnology, 13: 131-141.

FELISBERTO, S. A. \& L. RODRIGUES. 2012. Dinâmica sucessional de comunidade de algas perifíticas em um ecossistema lótico subtropical. Rodriguésia, 63(2): 463-473.

FERMINO, F. S., C. E. M. BICUDO \& D. C. BICUDO. 2011. Seasonal influence of nitrogen and phosphorus enrichment on the floristic composition of the algal periphytic community in a shallow tropical, mesotrophic reservoir (São Paulo, Brazil). Oecologia Australis, 15: 476-493.

FONSECA, B. M. \& C. E. M. BICUDO. 2010. How important can the presence/absence of macrophytes be in determining phytoplankton strategies in two tropical shallow reservoirs with different trophic status? Journal of Plankton Research, 32(1): 31-46.

FRANÇA, R. C. S., M. R. M. LOPES \& C. FERRAGUT. 2011. Structural and successional variability of periphytic algal community in a Amazonian lake during the dry and rainy season (Rio Branco, Acre). Acta Amazonica 41(2): 257-266.

GOLTERMAN, H. L. \& R. S. CLYMO. 1971. Methods for Chemical Analysis of Freshwaters. International Biological Programme. Blackwell Scientific Publications, Oxford, Edinburg.

GOLTERMAN, H. L., R. S. CLYMO \& M. A. OHNSTAD. 1978. Methods for physical and chemical analysis of freshwaters. $2^{\text {nd }}$ ed. Blackwell, Oxford, UK.

HAPPEY-WOOD, V. M. 1988. Ecology of freshwater planktonic green algae. In: Growth and reproductive strategies of freshwater phytoplankton. SANDGREEN, C. D. (ed): 175-226. Cambridge: Press Syndicate of the University of Cambridge.

HILLEBRAND, H., C. D. DÜRSELEN, D. KIRSCHTEL, U. POLLINGHER \& T. ZOHARY. 1999. Biovolume calculation for pelagic and benthic microalgae. Journal of Phycology, 35: 303-424.

HILLEBRAND, H. \& U. SOMMER. 2000. Diversity of benthic microalgae in response to colonization time and eutrophication. Aquatic Botany, 67(3): 221-236.
LEE, R. E. 2008. Phycology. Cambridge University Press. Cambridge. 547 pp.

LUND, J. W. G., C. KIPLING \& E. D. LE-CREN. 1958. The inverted microscope method of estimating algal number and the statistical basis of estimating by counting. Hydrobiologia, 11: 143-170.

MACKERET, F. J .H., J. HERON \& J. F. TALLING. 1978. Water analysis: some revised methods for limnologists. Cumbria: Freshwater Biological (Association. Scientific Publication, 39). Ed. Wilson, Son Ltda, Kendall, p. 117.

MARKER, A. F. H., H. NUSCH, H. RAI \& B. RIEMANN. 1980. The measurement of photosynthetic pigments in freshwaters and standardization of methods: conclusion and recomendations. Archive für Hydrobiologie, 14: 91-106.

MAGURRAN, A. E. 2004. Measuring Biological Diversity. Blackwell Science Ltd, Oxford. 256 pp.

MCCUNE, B. \& M. J. MEFFORD. 2011. PC-ORD. Multivariate analysis of ecological data. Version 6.0. MjM Software. Gleneden Beach, Oregon.

MCCORMICK, P. V. \& R. J. STEVENSON. 1991. Mechanisms of Benthic Algal Succession in Lotic Environments. Ecology, 72(5): 1835-1848.

PELLEGRINI, B. G. \& C. FERRAGUT. 2012. Variação sazonal e sucessional da comunidade de algas perifíticas em substrato natural em um reservatório mesotrófico tropical. Acta Botanica Brasilica, 26(4): 807-818.

RODRIGUES, L. \& D. C. BICUDO. 2004. Periphytic algae. In: The upper Paraná River and its floodplain: physical aspects, ecology and conservation. Thomaz, S. M., A. A. Agostinho \& N. S. Hahn (Eds): 125-143. Backhuys Publishers, Leiden.

SANDGREN, C. D. 1988. The ecology of chrysophyte flagellates: their growth and perennation strategies as freshwater phytoplankton. In: Growth and reproductive strategies of freshwater phytoplankton. Sandgren, C. D. (Ed): 9-104. Cambridge University Press, Cambridge.

SARTORY, D. P. \& J. U. GROBBELAAR. 1984. Extraction of chlorophyll a from freshwater phytoplankton for spectrophotometric analysis. Hydrobiologia, 114(3): 177-187.

SEKAR, R., V. P. VENUGOPALAN, K. V. K. NAIR \& V. N. R. RAO. 2002. Nutrients dynamics and successional changes in a lentic freshwater biofilm. Freshwater Biology, 47: 1893-1907.

SEKAR, R., K. V. K. NAIR, K. NANDAKUMAR, V. P. VENUGOPALAN \& V. N. R. RAO. 2004. Early stages of biofilm succession in a lentic freshwater 
environment. Hydrobiologia, 512: 97-108.

STEVENSON, R. J. 1996. An introduction to algal ecology in freshwater benthic habitats. In: Algal Ecology: freshwater benthic ecosystems. STEVENSON, R. J., M. L. BOTHWELL \& R. L. LOWE. (Eds.): 3-30. Academic Press, San Diego.

UTERMÖHL, H. 1958. Zur Vervollkommnung der quantitativen Phytoplankton-Methodik. Mitteilungen der Internationalen Vereinigung für Theoretis- che und Angewandte Limnologie, 9: 1-38.

VALDERRAMA, G. C. 1981. The simultaneous analysis of total nitrogen and total phosphorus in natural waters. Marine Chemical, 10: 109-112.

VERCELLINO, I. S. \& D. C. BICUDO. 2006. Sucessão da comunidade de algas perifíticas em reservatório oligotrófico tropical (São Paulo, Brasil): Comparação entre período seco e chuvoso. Revista Brasileira de Botânica, 29: 363-377. 
